\title{
MULTIPLE CRITERIA SELECTION OF PILE-COLUMN CONSTRUCTION TECHNOLOGY
}

\author{
Edmundas Kazimieras Zavadskas ${ }^{1}$, Saulius Sušinskas ${ }^{2}$, Alfonsas Daniūnas ${ }^{3}$, \\ Zenonas Turskis ${ }^{4}$, Henrikas Sivilevičius ${ }^{5}$

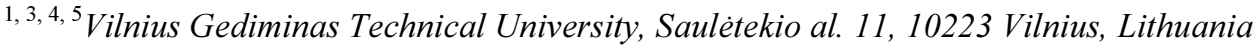 \\ ${ }^{2}$ Kaunas University of Technology Panevežys Institute, S. Daukanto g. 12-138, 37164 Panevežys, Lithuania

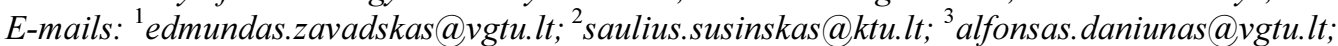 \\ ${ }^{4}$ zenonas.turskis@vgtu.lt (corresponding author); ${ }^{5}$ henrikas.sivilevicius@vgtu.lt \\ Received 20 Dec. 2010; accepted 04 Nov. 2011
}

\begin{abstract}
Numerous alternatives exist for foundation systems and construction technologies. The systems can be described by different criteria values which are incorporated in the conventional design process. Decision on the most suitable construction technology is vital for success and depends on many effectiveness criteria. The business success depends on the right choice. The mandate of a construction management researcher is to use rational, systematic, science-based techniques to inform and improve various decisions. The paper presents multiple criteria decision making model for selection of a pile-column technology. The technological criteria are determined by an experimental study. Based on in-situ investigation of natural soil conditions, criteria values are determined. The decision making model incorporates five different methods and techniques. To solve a problem, it uses three multiple criteria decision making methods. Integrated criteria weights are determined by using the analytic hierarchy process and the expert judgement method. This model could be used to solve complicated problems pertaining to the selection of a construction technology.
\end{abstract}

Keywords: pile-columns, technology, multiple criteria, construction site, MCDM, TOPSIS, ARAS, COPRAS, AHP, the expert judgement method, integrated weights.

\section{Introduction}

In construction, piles can be used in various ways. In urban areas, many high-rise buildings and viaducts are founded on a pile foundation. Construction technologies are highly dependent on in-situ conditions, e.g. soil conditions are particularly important for a foundation. The way the designed and actual founding depths of foundations correspond to variability of geological conditions has long been a concern (Zhang et al. 2011b). Tomlinson and Woodward (2008) presented a lot of pile design examples. Sivilevičius et al. (2012) presented results of an experimental study on technological indicators of pilecolumns at a construction site. Based on in-situ investigation of natural soil conditions, regression equations have been determined, which can be very useful when planning similar works at a construction site. Besides, they allow determining duration and energy consumption of construction works. Zhang and Dasaka (2010) evaluated the spatial variability characteristics at a weathered soil site. Sušinskas et al. (2011) presented the process for selection of the most fitting and effective pile-column instalment alternative. The model is based on ARAS method and AHP technique. Zhang et al. (2011a) proposed a two-stage analysis method to study the behaviour of pile groups with rigid elevated caps. A single pile foundation utilizes a single, generally a large-diameter structural element to support all of the loads (weight, wind, etc.) of a large above-surface structure. Yoon et al. (2011) presented the evaluation results of the load test on columns and the rationale used for the selection of the resistance factor. Zhao et al. (2009) presented the model for stability analysis of high pile-column bridge pier. Zhang et al. (2011b) analysed excavation-induced responses of loaded pile foundations considering the uploading effect. Zhao et al. (2007) revisited the stability analysis regarding the pile-columns of a bridge pier.

Sustainable development aims to reconcile economic growth, social progress and frugal use of natural resources, to maintain ecological balance and to ensure favourable living conditions for current and future generations (Raslanas et al. 2011). Selection of an investment strategy and related decision making relies heavily on personal experience and behaviour (Wu et al. 2012; Šaparauskas et al. 2011; Banaitienè et al. 2011). Multiple criteria decision making is an important part of modern decision science (Zavadskas, Turskis 2011; Zavadskas et al. 2008). How to select an effective algorithm for a multiclass classification task is an important yet difficult issue (Peng et al. 2011). Most of the real-world multiple criteria decisionmaking problems contain a mixture of quantitative and qualitative criteria (Nieto-Morote, Ruz-Vila 2011; Kaklauskas et al. 2011; Merigo, Gil-Laufente 2011). The typical MCDM problem is concerned with the task of ranking. In order to evaluate the overall efficiency of technological alternatives, typically it is necessary: a) to identify 
the system for evaluation of criteria that relates the system capabilities to goals; b) to develop alternative systems for attaining the goals (generating alternatives); c) to assess a finite number of decision alternatives, each of which is described in terms of different decision criteria which are taken into account simultaneously; d) to apply a normative multiple criteria analysis method; e) to accept one alternative as the most preferable; $f$ ) to gather new information and go into the next iteration of multiple criteria optimization if the final solution is not accepted.

At the beginning of his book, Zeleny (1982) stated that "It has become more and more difficult to see the world around us in a unidimensional way and to use only a single criterion when judging what we see". In reality, the modelling of engineering problems is based on a different kind of logic taking into consideration the existence of multiple criteria, the conflicting aims of decision maker, the complex, subjective and different nature of the evaluation process, and the participation of several decision makers. The use of the new and modernisation of the existing technologies as well as the selection of the most suitable alternative among those feasible with the help of different models are challenging tasks for the modern civil engineering (Prentkovskis et al. 2012; Krayushkina et al. 2012). Estimation and modelling of problems depends the recent advances achieved in different fields (Dzemyda, Sakalauskas 2011). Selection of the right construction technology plays a vital role in the overall performance of a project, thus posing the most crucial challenge for any contractor. Numerous and often conflicting objectives and alternatives, such as tender price, completion date, and experience, need to be considered. Recently, to assist contractors and stakeholders in decision-making, there has been a trend to move away from the "lowest-price wins" principle and subjective judgement to the multiple criteria selection approach in the selection of alternatives (San Cristóbal 2012).

\section{Case study}

Projects with pile-columns are complex systems that are rather difficult to select in practice. For this reason, a decision-maker should possess a large amount of multidisciplinary knowledge and be familiar with multidisciplinary techniques of operations research. The case study presents the process of selecting the pile-column alternative for a building that stands on the aquiferous soil. The aim of the study is to design and install the most effective pile-columns. The study shows how a decision-maker can find the most reasonable alternative with the help of a certain dataset. Taking into account the aforementioned suggestions and references of experts as well as the aim to install the most effective pile-columns, the five following alternatives were considered (Table 1).

Table 1. Considered technological alternatives for installing pile-columns (driving the rings)

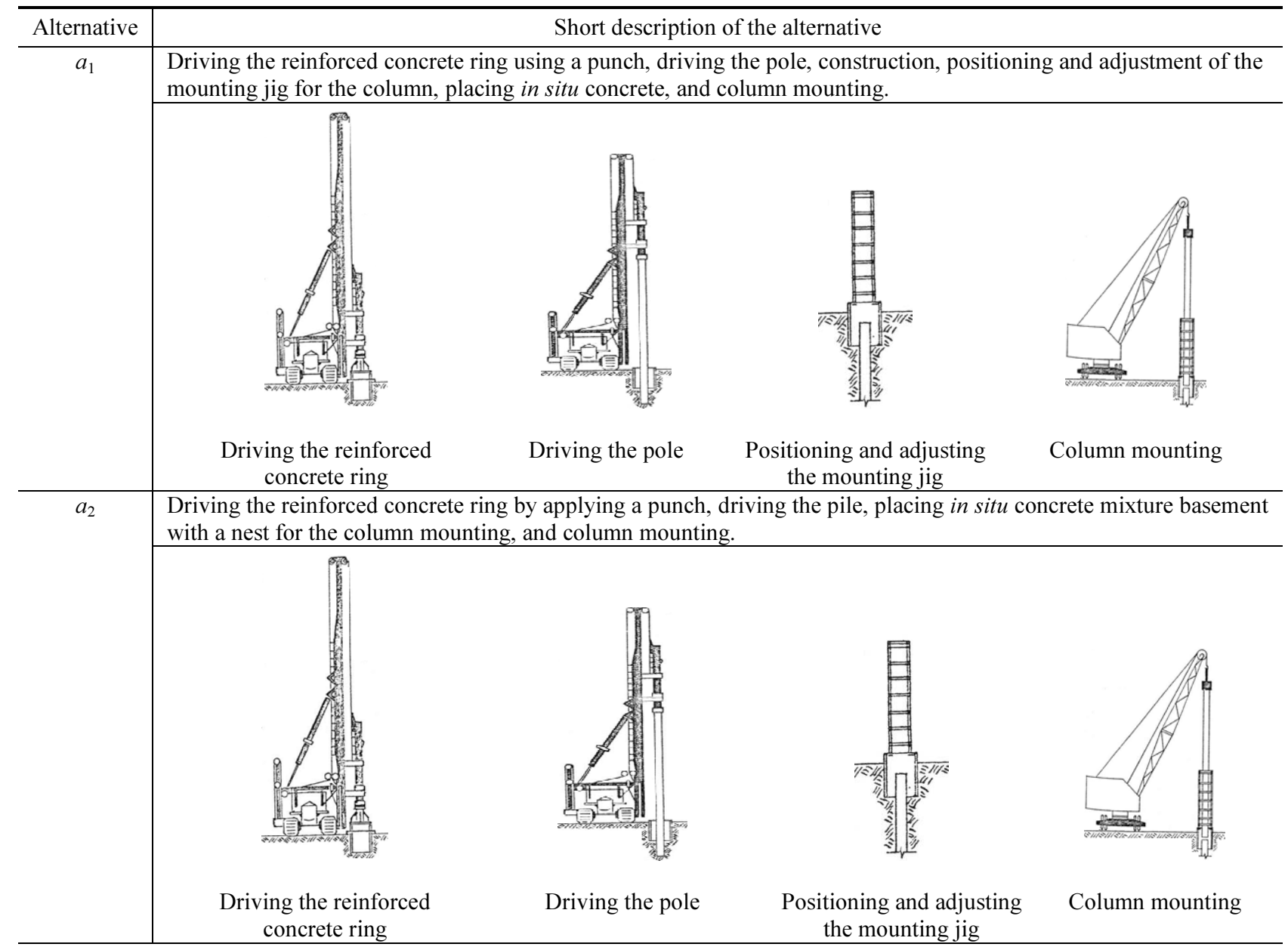


Continue of Table 1

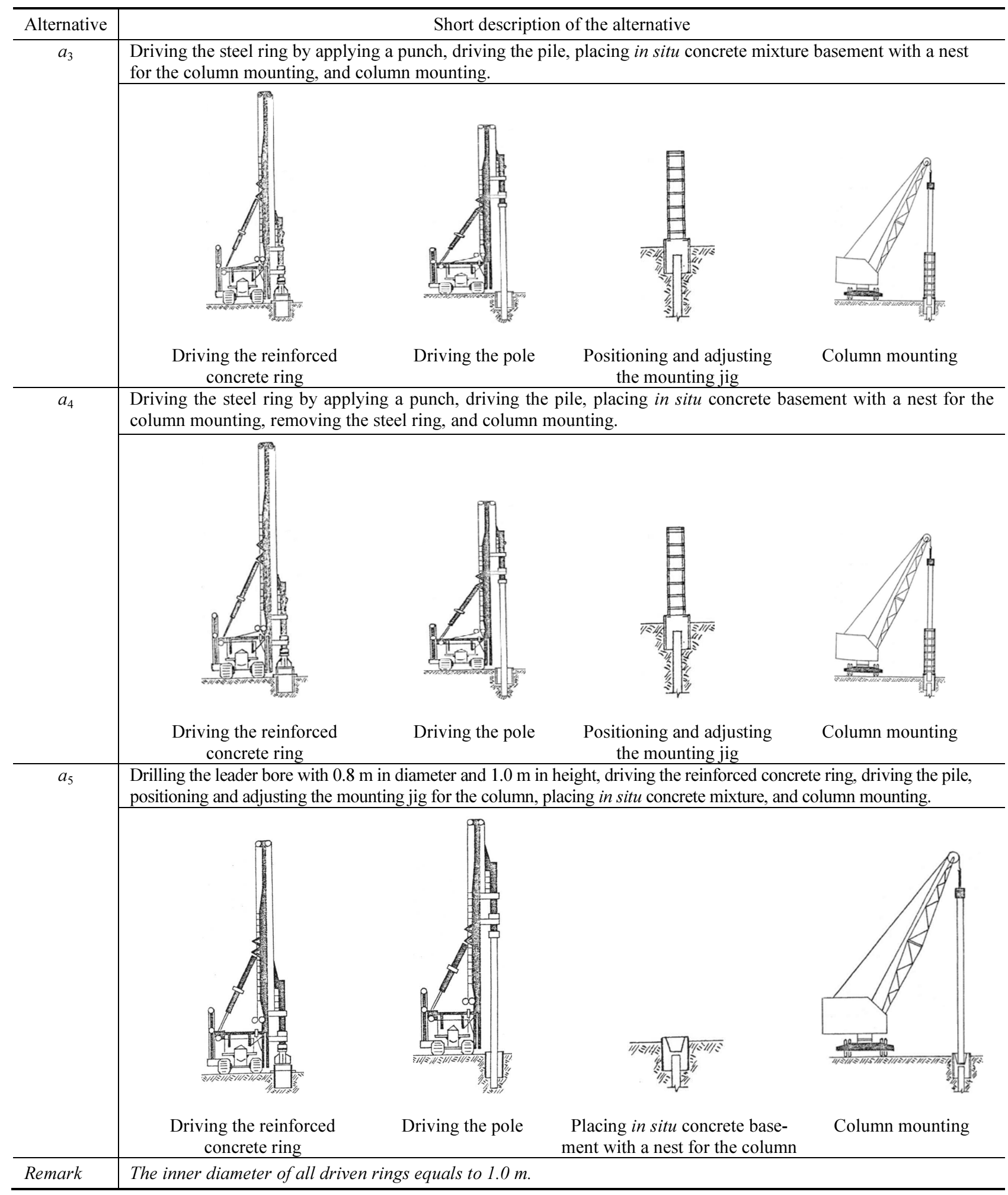

The construction technology of alternatives is described by six criteria. The set of criteria was determined by qualified civil engineers and shown in Table 2 . The selection is based on a set of criteria: labour expenditures ( $x_{1}$, hours), cost of instalment $\left(x_{2}, €\right)$, consumption of concrete $\left(x_{3}, \mathrm{~m}^{3}\right)$, consumption of steel $\left(x_{4}, \mathrm{~kg}\right)$, machinery expenditures $\left(x_{5}\right.$, hours), and consumption of energy $\left(x_{6}, \mathrm{GJ}\right)$. The criteria set for evaluation is selected considering the factors that influence the efficiency of the construction process. Significance of criteria significances (weights) was determined with the help of the expert judgement method and the analytic hierarchy process (AHP) method. Integrated criteria weights were applied in the solution process. 
Table 2. The Expert judgement method

\begin{tabular}{|c|c|c|c|c|c|c|}
\hline Expert & $x_{1}$ & $x_{2}$ & $x_{3}$ & $x_{4}$ & $x_{5}$ & $x_{6}$ \\
\hline$E_{1}$ & 5 & 6 & 4 & 3 & 1 & 2 \\
\hline$E_{2}$ & 1 & 5 & 6 & 3 & 2 & 4 \\
\hline$E_{3}$ & 3 & 5 & 6 & 4 & 1 & 2 \\
\hline $\mathrm{E}_{4}$ & 5 & 4 & 6 & 3 & 1 & 2 \\
\hline $\mathrm{E}_{5}$ & 6 & 5 & 3 & 4 & 2 & 1 \\
\hline$E_{6}$ & 3 & 4 & 6 & 5 & 2 & 1 \\
\hline $\mathrm{E}_{7}$ & 4 & 6 & 5 & 3 & 1 & 2 \\
\hline$E_{8}$ & 1 & 3 & 5 & 4 & 2 & 6 \\
\hline $\mathrm{E}_{9}$ & 5 & 6 & 3 & 4 & 1 & 2 \\
\hline$E_{10}$ & 6 & 5 & 3 & 4 & 1 & 2 \\
\hline $\mathrm{E}_{11}$ & 5 & 6 & 4 & 3 & 2 & 1 \\
\hline$E_{12}$ & 5 & 6 & 3 & 2 & 4 & 1 \\
\hline$E_{13}$ & 5 & 2 & 6 & 4 & 3 & 1 \\
\hline$E_{14}$ & 4 & 3 & 6 & 5 & 1 & 2 \\
\hline$E_{15}$ & 6 & 5 & 3 & 4 & 2 & 1 \\
\hline $\mathrm{E}_{16}$ & 3 & 4 & 6 & 5 & 1 & 2 \\
\hline$E_{17}$ & 5 & 6 & 4 & 3 & 2 & 1 \\
\hline $\mathrm{E}_{18}$ & 5 & 6 & 3 & 4 & 2 & 1 \\
\hline$E_{19}$ & 6 & 4 & 5 & 3 & 1 & 2 \\
\hline$E_{20}$ & 5 & 6 & 4 & 3 & 1 & 2 \\
\hline$E_{21}$ & 4 & 6 & 5 & 3 & 2 & 1 \\
\hline$E_{22}$ & 4 & 6 & 3 & 5 & 1 & 2 \\
\hline$E_{23}$ & 5 & 6 & 1 & 2 & 4 & 3 \\
\hline$E_{24}$ & 5 & 6 & 3 & 4 & 1 & 2 \\
\hline$E_{25}$ & 5 & 6 & 2 & 4 & 3 & 1 \\
\hline$E_{26}$ & 5 & 6 & 4 & 3 & 1 & 2 \\
\hline Sum of ranks & 116 & 133 & 109 & 94 & 45 & 49 \\
\hline Mean value & 4.462 & 5.115 & 4.192 & 3.615 & 1.731 & 1.885 \\
\hline Rank & 2 & 1 & 3 & 4 & 6 & 5 \\
\hline $\begin{array}{l}\text { Weight of } \\
\text { criterion } p_{j}\end{array}$ & 0.212 & 0.244 & 0.200 & 0.172 & 0.082 & 0.090 \\
\hline
\end{tabular}

\subsection{Determining criteria weights}

One of the major tasks is to determine the weights of the criteria. The weights demonstrate which criterion is the most important in comparison to the other criteria (Kersuliene et al. 2010). The expert judgment method was applied (Kendall 1970) at the first stage of criteria weight determination. Zavadskas et al. (2010a) provided a detailed presentation of the algorithm and discussed peculiarities of weight determination. The weights $p_{j}$ of attributes presented in Table 1 were determined by application of the expert judgment method proposed by Kendall. This expert judgment method was implemented at the following stages: a) calculation of values $t$; b) calculation of weights $w$; c) calculation of values $S$; d) calculation of values $T_{k}$; e) calculation of concordance value $W ; \mathrm{f}$ ) calculation of values $\chi^{2} ; \mathrm{g}$ ) testing the statement $\chi^{2}>\chi_{t b l}^{2}$.

The values $t_{j k}$ for statistical processing were obtained by interviewing the respondents.

Kendall (1970) has demonstrated that, when $n>7$, the value $\chi_{\alpha, v}^{2}=W \cdot r \cdot(n-1)$ has a distribution with degrees of freedom $v=n-1$, where $n$ is the number of attributes considered and $r$ - the number of experts. If the calculated value $\chi^{2}$ is larger than the critical tabular value $\chi^{2}{ }_{t b l}$ for the pre-selected level of significance $\alpha$, then the hypothesis about the agreement of independent expert judgments is not rejected. In the case study, the number of experts $r=26$, the degrees of freedom $v=n-1=5$ and the pre-selected level of significance is $\alpha=0.05$. The calculated concordance coefficient based on the weights of attributes is $W=0.558$. The tabular value $\chi_{t b l}^{2}=15.08(\alpha=0.05)$ (Fisher, Yates 1963).

Since $\chi_{t b l}^{2}=15.08>\chi_{\alpha, \nu}^{2}=72.55$ then the assumption is made that the coefficient of concordance is significant and expert rankings are in concordance with $95 \%$ probability.

During the next step, experts applied the WEAR software (which contains the AHP method) to determine criteria weights (Zavadskas et al. 2012) (see Table 3).

In decision analysis, the analytical hierarchy process (AHP) and the analytical network process (ANP) are widely used to assess the key factors and analyse the impacts and preferences of decision alternatives (Ergu et al. 2011a, b).

The recent developments of decision making models based on the AHP (Saaty 1980; Saaty, Zoffer 2011; Vaidogas, Sakenaite 2011) methods are listed below: Medineckiene et al. (2010) applied the AHP in sustainable construction; Maskeliūnaitè et al. (2009), Sivilevičius and Maskeliūnaitè (2010), and Sivilevičius (2011a) applied the AHP in modelling of transport systems; and Sivilevičius (2011b) used the AHP to determine the quality of technology.

Table 3. Criteria weights according to the AHP method

\begin{tabular}{|c|c|c|c|c|c|c|c|}
\hline \multicolumn{7}{|c|}{ Determined criteria weights } & \\
\hline Expert & $x_{1}$ & $x_{2}$ & $x_{3}$ & $x_{4}$ & $x_{5}$ & $x_{6}$ & \\
\hline$E_{1}$ & \begin{tabular}{|l|}
0.249 \\
\end{tabular} & 0.379 & 0.102 & 0.16 & 0.043 & 0.065 & \\
\hline $\mathrm{E}_{2}$ & 0.043 & 0.249 & 0.379 & 0.16 & 0.065 & 0.102 & \\
\hline $\mathrm{E}_{3}$ & 0.16 & 0.249 & 0.379 & 0.102 & 0.043 & 0.065 & \\
\hline $\mathrm{E}_{4}$ & 0.249 & 0.102 & 0.379 & 0.16 & 0.043 & 0.065 & \\
\hline$E_{5}$ & 0.379 & 0.249 & 0.16 & 0.102 & 0.065 & 0.043 & \\
\hline $\mathrm{E}_{6}$ & 0.16 & 0.102 & 0.379 & 0.249 & 0.065 & 0.043 & \\
\hline $\mathrm{E}_{7}$ & 0.102 & 0.379 & 0.249 & 0.16 & 0.043 & 0.065 & \\
\hline $\mathrm{E}_{8}$ & 0.043 & 0.16 & 0.249 & 0.102 & 0.065 & 0.379 & \\
\hline $\mathrm{E}_{9}$ & 0.249 & 0.379 & 0.16 & 0.102 & 0.043 & 0.065 & \\
\hline $\mathrm{E}_{10}$ & \begin{tabular}{|l|}
0.379 \\
\end{tabular} & \begin{tabular}{|l|}
0.249 \\
\end{tabular} & 0.16 & 0.102 & 0.043 & 0.065 & \\
\hline $\mathrm{E}_{11}$ & \begin{tabular}{|l|}
0.249 \\
\end{tabular} & \begin{tabular}{|l|}
0.379 \\
\end{tabular} & 0.102 & 0.16 & 0.065 & 0.043 & \\
\hline$E_{12}$ & \begin{tabular}{|l|}
0.249 \\
\end{tabular} & \begin{tabular}{|l|}
0.379 \\
\end{tabular} & 0.16 & 0.065 & 0.102 & 0.043 & \\
\hline$E_{13}$ & \begin{tabular}{|l}
0.249 \\
\end{tabular} & 0.065 & 0.379 & 0.102 & 0.16 & 0.043 & \\
\hline$E_{14}$ & \begin{tabular}{|l|}
0.102 \\
\end{tabular} & 0.16 & 0.379 & 0.249 & 0.043 & 0.065 & \\
\hline $\mathrm{E}_{15}$ & \begin{tabular}{|l|}
0.379 \\
\end{tabular} & \begin{tabular}{|l|}
0.249 \\
\end{tabular} & 0.16 & 0.102 & 0.065 & 0.043 & \\
\hline $\mathrm{E}_{16}$ & 0.16 & 0.102 & 0.379 & 0.249 & 0.043 & 0.065 & \\
\hline$E_{17}$ & \begin{tabular}{|l|}
0.249 \\
\end{tabular} & \begin{tabular}{|l|}
0.379 \\
\end{tabular} & 0.102 & 0.16 & 0.065 & 0.043 & \\
\hline$E_{18}$ & \begin{tabular}{|l|}
0.249 \\
\end{tabular} & \begin{tabular}{|l|}
0.379 \\
\end{tabular} & 0.16 & 0.102 & 0.065 & 0.043 & \\
\hline$E_{19}$ & \begin{tabular}{|l|}
0.379 \\
\end{tabular} & \begin{tabular}{|l|l|}
0.102 \\
\end{tabular} & 0.249 & 0.16 & 0.043 & 0.065 & \\
\hline$E_{20}$ & \begin{tabular}{|l|}
0.249 \\
\end{tabular} & \begin{tabular}{|l|}
0.379 \\
\end{tabular} & 0.102 & 0.16 & 0.043 & 0.065 & \\
\hline$E_{21}$ & \begin{tabular}{|l|}
0.102 \\
\end{tabular} & \begin{tabular}{|l|}
0.379 \\
\end{tabular} & 0.249 & 0.16 & 0.065 & 0.043 & \\
\hline$E_{22}$ & \begin{tabular}{|l|l}
0.102 \\
\end{tabular} & \begin{tabular}{|l|}
0.379 \\
\end{tabular} & 0.16 & 0.249 & 0.043 & 0.065 & \\
\hline$E_{23}$ & \begin{tabular}{|l}
0.249 \\
\end{tabular} & \begin{tabular}{|l|}
0.379 \\
\end{tabular} & 0.043 & 0.065 & 0.102 & 0.16 & \\
\hline$E_{24}$ & \begin{tabular}{|l|}
0.249 \\
\end{tabular} & \begin{tabular}{|l|}
0.379 \\
\end{tabular} & 0.16 & 0.102 & 0.043 & 0.065 & \\
\hline$E_{25}$ & \begin{tabular}{|l|}
0.249 \\
\end{tabular} & 0.379 & 0.065 & 0.102 & 0.16 & 0.043 & \\
\hline$E_{26}$ & \begin{tabular}{|l}
0.249 \\
\end{tabular} & \begin{tabular}{|l}
0.379 \\
\end{tabular} & 0.102 & 0.16 & 0.043 & 0.065 & $\sum \sum$ \\
\hline \multirow[t]{2}{*}{$\sum$} & 5.727 & 7.344 & 5.547 & 3.746 & 1.668 & 1.916 & 25.948 \\
\hline & \multicolumn{6}{|c|}{ Established weights } & \\
\hline$q_{\mathrm{j}}$ & 0.221 & 0.283 & 0.214 & 0.144 & 0.064 & 0.074 & \\
\hline
\end{tabular}


Integrated criteria weights were calculated during the third stage of criteria weight determination (Table 4).

Table 4. Integrated criteria weights

\begin{tabular}{|c|c|c|c|c|c|c|c|}
\hline & \multicolumn{6}{|c|}{ Criteria } & Weights \\
\hline & $\bar{x}$ & $\overbrace{}^{\prime}$ & $\approx$ & $\underset{t}{*}$ & $\approx$ & $x^{\circ}$ & \\
\hline$q_{\mathrm{j}}$ & $\begin{array}{l}\overline{\mathrm{J}} \\
0\end{array}$ & $\begin{array}{l}\text { مै } \\
\text { ஸे } \\
0\end{array}$ & $\left|\begin{array}{c}\frac{\pi}{N} \\
0\end{array}\right|$ & $\frac{f}{\dot{0}}$ & $\begin{array}{l}\text { ț } \\
\stackrel{0}{0}\end{array}$ & 㕝 & AHP \\
\hline$p_{\mathrm{j}}$ & 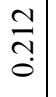 & $\begin{array}{l}\stackrel{J}{ \pm} \\
\stackrel{\Delta}{0}\end{array}$ & $\mid \begin{array}{l}1 \\
0\end{array}$ & $\stackrel{N}{\Xi}$ & $\begin{array}{l}\text { Oे } \\
\stackrel{0}{0}\end{array}$ & $\stackrel{\partial}{0}$ & Kendall \\
\hline$w_{j}$ & 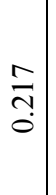 & 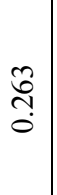 & 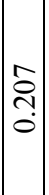 & $\stackrel{\infty}{\stackrel{\infty}{0}}$ & $\stackrel{\overbrace{}}{0}$ & $\begin{array}{l}\tilde{O} \\
\stackrel{0}{0} \\
\stackrel{0}{0}\end{array}$ & $\begin{array}{l}\text { Integrated } \\
w_{j}=\frac{q_{j} p_{j}}{\sum_{j=1}^{n}\left(q_{j} p_{j}\right)} ; j=\overline{1, n}\end{array}$ \\
\hline
\end{tabular}

\subsection{Problem solving}

Three different multiple criteria decision making methods - TOPSIS, COPRAS and ARAS - were selected to solve the investigated problem An Additive Ratio Assessment (ARAS) method (Zavadskas, Turskis 2010; Turskis, Zavadskas 2010a) is based on the argument that complicated phenomena could to be understood by using simple relative comparisons. It is argued that the ratio of the sum of normalised and weighted values of criteria, which describe an alternative under consideration, to the sum of the values of normalised and weighted criteria, which describes the optimal alternative, is the degree of optimality, which is reached by the alternative under comparison.

The recent developments of decision making models based on the ARAS method are listed below: Keršulienè and Turskis (2011) presented an integrated fuzzy multiple criteria decision making model for the selection of an architect; Turskis and Zavadskas (2010b) performed multiple criteria analysis in order to select the location for a logistics centres; and Zavadskas et al. (2010b) analysed foundation alternatives.

The method of complex proportional assessment COPRAS (Zavadskas, Kaklauskas 1996) assumes direct and proportional dependence of significance and utility degree of investigated alternatives on a system of criteria adequately describing the alternatives, and on values and weights of the criteria. This method was used to solve various problems in construction.

The recent developments of decision making models based on COPRAS methods (Podvezko 2011) are listed below: Datta et al. (2009) solved the problem of determining the compromise to selection of a supervisor; Bindu Madhuri et al. (2010) presented the model for selection of alternatives based on COPRAS-G and AHP methods; Uzsilaityte and Martinaitis (2010) investigated and compared different alternatives for the renovation of buildings taking into account energy, economic and environmental criteria while evaluating impact of renovation measures during their life cycle; Chatterjee et al. (2011) presented materials selection model based on COPRAS and EVAMIX methods; Yazdani et al. (2011) applied the COPRAS method to analyse critical infrastructures.

The TOPSIS (Technique for Order Preference by Similarity to Ideal Solution) method determines a solution with the shortest distance from the ideal solution and the farthest distance from the negative-ideal solution (Hwang, Yoon 1981). Kalibatas et al. (2011) used it in order to solve the problem of the assessment of dwellinghouses, determining the ideal indoor environment. Rudzianskaite-Kvaraciejiene et al. (2010) evaluated the effectiveness of road investment projects. ble 5 .

The description of the methods is presented in Ta-

First of all, the initial decision making matrix was prepared. The problem was solved by applying three different multiple criteria decision making methods: TOPSIS, COPRAS and ARAS. The solution process of the problem is presented in Table 6 .

Table 5. Description of TOPSIS, COPRAS and ARAS methods

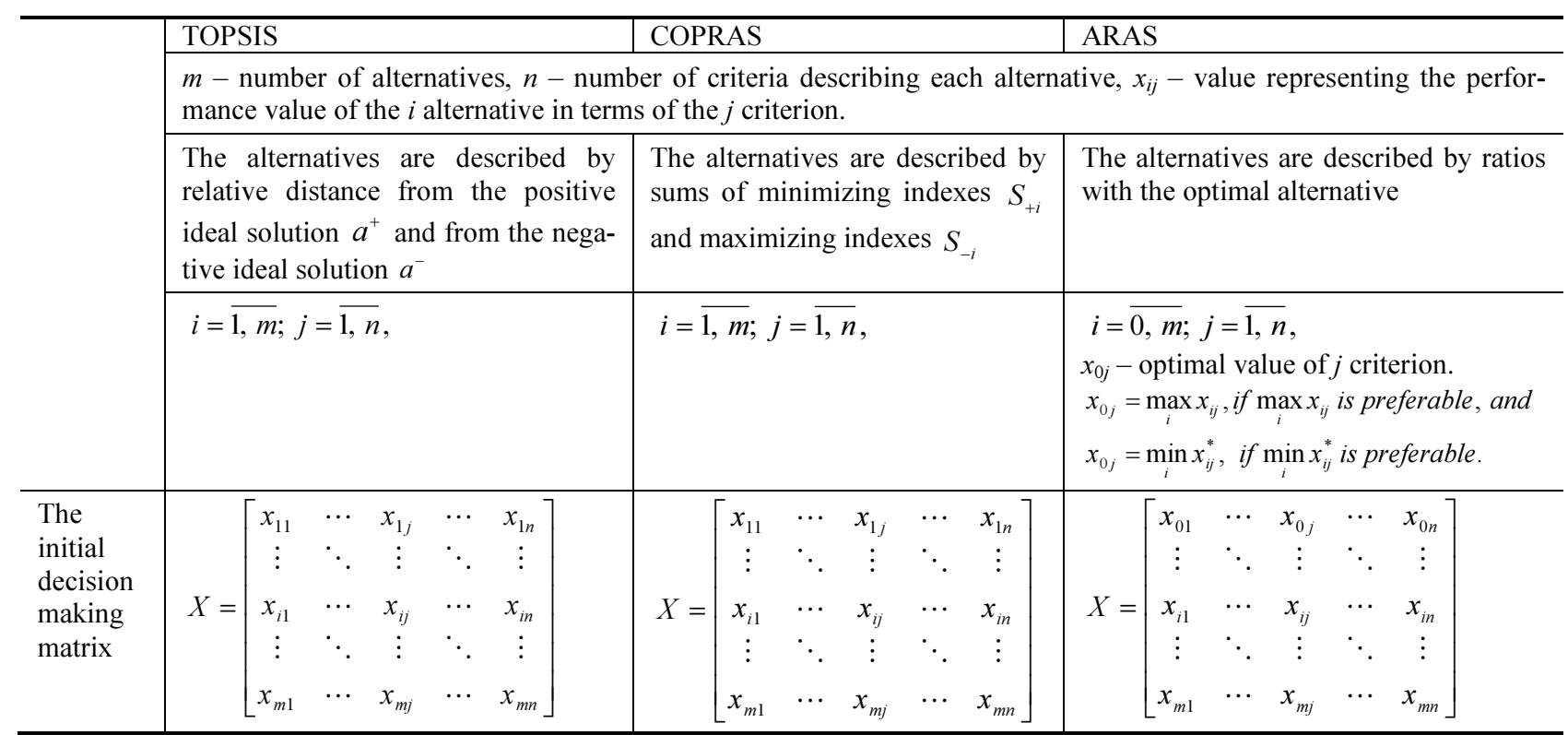


Continue of Table 5

\begin{tabular}{|c|c|c|c|}
\hline & TOPSIS & COPRAS & ARAS \\
\hline $\begin{array}{l}\text { Normali- } \\
\text { sation of } \\
\text { the initial } \\
\text { decision } \\
\text { making } \\
\text { matrix }\end{array}$ & $\bar{x}_{i j}=\frac{x_{i j}}{\left(\sum_{i=1}^{m}\left(x_{i j}\right)^{2}\right)^{0.5}}$ & $\bar{x}_{i j}=\frac{x_{i j}}{\sum_{i=1}^{m} x_{i j}}$ & $\begin{array}{l}\bar{x}_{i j}=\frac{x_{i j}}{\sum_{i=0}^{m} x_{i j}} \text {, if } \max _{i} x_{i j} \text { is preferable } \\
\bar{x}_{i j}=\frac{1}{x_{i j} \sum_{i=0}^{m} \frac{1}{x_{i j}}} \text {, if } \min _{i} x_{i j}^{*} \text { is preferable. }\end{array}$ \\
\hline $\begin{array}{l}\text { Normali- } \\
\text { sed ma- } \\
\text { trix }\end{array}$ & $\bar{X}=\left[\begin{array}{ccc}\bar{x}_{11} & \cdots & \bar{x} \\
\vdots & \ddots & \\
\bar{x}_{i 1} & \cdots & \bar{x} \\
\vdots & \ddots & \\
\bar{x}_{m 1} & \cdots & \bar{x}\end{array}\right.$ & $\left.\begin{array}{cc}\cdots & \bar{x}_{1 n} \\
\ddots & \vdots \\
\cdots & \bar{x}_{i n} \\
\ddots & \vdots \\
\cdots & \bar{x}_{m n}\end{array}\right]$ & $\bar{X}=\left[\begin{array}{ccccc}\bar{x}_{01} & \cdots & \bar{x}_{0 j} & \cdots & \bar{x}_{0 n} \\
\vdots & \ddots & \vdots & \ddots & \vdots \\
\bar{x}_{i 1} & \cdots & \bar{x}_{i j} & \cdots & \bar{x}_{i n} \\
\vdots & \ddots & \vdots & \ddots & \vdots \\
\bar{x}_{m 1} & \cdots & \bar{x}_{m j} & \cdots & \bar{x}_{m n}\end{array}\right]$ \\
\hline $\begin{array}{l}\text { Weigh- } \\
\text { ting of } \\
\text { normali- } \\
\text { sed } \\
\text { matrix }\end{array}$ & & $\hat{x}_{i j}=\bar{x}_{i j} w_{j}$ & \\
\hline $\begin{array}{l}\text { Deter- } \\
\text { mining } \\
\text { the ideal } \\
\text { positive } \\
\text { and the } \\
\text { ideal } \\
\text { negative } \\
\text { solution }\end{array}$ & $\begin{array}{l}a^{+}=\left\{\hat{x}_{1}^{+}, \ldots, \hat{x}_{n}^{+}\right\}= \\
=\left\{\left(\max _{i} \hat{x}_{i j} \| i \in I^{\prime}\right),\left(\min _{i} \hat{x}_{i j} \| i \in I^{\prime \prime}\right)\right\} \\
a^{-}=\left\{\hat{x}_{1}^{-}, \ldots, \hat{x}_{n}^{-}\right\}= \\
=\left\{\left(\min _{i} \hat{x}_{i j} \| i \in I^{\prime}\right),\left(\max _{i} \hat{x}_{i j} \| i \in I^{\prime \prime}\right)\right\}\end{array}$ & & \\
\hline $\begin{array}{l}\text { Normali- } \\
\text { sed- } \\
\text { weighted } \\
\text { matrix }\end{array}$ & $\hat{X}=\left[\begin{array}{ccccc}\hat{x}_{11} & \cdots & \hat{x}_{1 j} & \cdots & \bar{x}_{1 n} \\
\vdots & \ddots & \vdots & \ddots & \vdots \\
\hat{x}_{i 1} & \cdots & \hat{x}_{i j} & \cdots & \hat{x}_{i n} \\
\vdots & \ddots & \vdots & \ddots & \vdots \\
\hat{x}_{m 1} & \cdots & \hat{x}_{m j} & \cdots & \hat{x}_{m n} \\
\hat{x}_{1}^{+} & \cdots & \hat{x}_{j}^{+} & \cdots & \hat{x}_{n}^{+} \\
\hat{x}_{1}^{-} & \cdots & \hat{x}_{j}^{-} & \cdots & \hat{x}_{n}^{-}\end{array}\right]$ & $\hat{X}=\left[\begin{array}{ccccc}\hat{x}_{11} & \cdots & \hat{x}_{1 j} & \cdots & \hat{x}_{1 n} \\
\vdots & \ddots & \vdots & \ddots & \vdots \\
\hat{x}_{i 1} & \cdots & \hat{x}_{i j} & \cdots & \hat{x}_{i n} \\
\vdots & \ddots & \vdots & \ddots & \vdots \\
\hat{x}_{m 1} & \cdots & \hat{x}_{m j} & \cdots & \hat{x}_{m n}\end{array}\right]$ & $\hat{X}=\left[\begin{array}{ccccc}\hat{x}_{01} & \cdots & \hat{x}_{0 j} & \cdots & \hat{x}_{0 n} \\
\vdots & \ddots & \vdots & \ddots & \vdots \\
\hat{x}_{i 1} & \cdots & \hat{x}_{i j} & \cdots & \hat{x}_{i n} \\
\vdots & \ddots & \vdots & \ddots & \vdots \\
\hat{x}_{m 1} & \cdots & \hat{x}_{m j} & \cdots & \hat{x}_{m n}\end{array}\right]$ \\
\hline $\begin{array}{l}\text { Deter- } \\
\text { mining } \\
\text { values } \\
\text { of the } \\
\text { optima- } \\
\text { lity } \\
\text { function }\end{array}$ & $\begin{array}{l}\text { The separations of each alternative } \\
\text { from the positive ideal solution } D_{i}^{+} \\
\text {and from the negative ideal solution } \\
D_{i}^{-} \text {in Euclidean distance are given } \\
\text { as } \\
D_{i}^{+}=\left(\sum_{j=1}^{n}\left(\hat{x}_{i j}-\hat{x}_{j}^{+}\right)^{2}\right)^{0.5} ; \\
D_{i}^{-}=\left(\sum_{j=1}^{n}\left(\hat{x}_{i j}-\hat{x}_{j}^{-}\right)^{2}\right)^{0.5}\end{array}$ & $\begin{array}{l}S_{+i}=\sum_{j=1}^{n} \hat{x}_{+i j}, \text { when } \max _{i} x_{i j} \text { is preferable } \\
S_{-i}=\sum_{j=1}^{n} \hat{x}_{-i j}, \text { when } \min _{i} x_{i j} \text { is preferable; } \\
S_{+}=\sum_{i=1}^{m} S_{+i}=\sum_{i=1}^{m} \sum_{j=1}^{n} \hat{x}_{+i j} \\
S_{-}=\sum_{i=1}^{m} S_{-i}=\sum_{i=1}^{m} \sum_{j=1}^{n} \hat{x}_{-i j} \\
S_{i}=S_{+i}+\frac{S_{-\min } \cdot \sum_{i=1}^{m} S_{-i}}{S_{-i} \cdot \sum_{i=1}^{m} S_{-\min } / S_{-i}}\end{array}$ & $S_{i}=\sum_{j=1}^{n} \hat{x}_{i j}$ \\
\hline $\begin{array}{l}\text { Utility } \\
\text { degree } \\
K_{i} \text { of } \\
\text { the } \\
\text { alterna- } \\
\text { tive } a_{i}\end{array}$ & $K_{i}=\frac{D_{i}^{-}}{D_{i}^{-}+D_{i}^{+}}$ & $K_{i}=\frac{S_{i}}{\max _{i} S_{i}}$ & $K_{i}=\frac{S_{i}}{S_{0}}$ \\
\hline $\begin{array}{l}\text { Ranking } \\
\text { of alter- } \\
\text { natives }\end{array}$ & \multicolumn{3}{|c|}{$\max _{i} K_{i}$, is the most preferable } \\
\hline
\end{tabular}


Table 6. The problem solution process and results

\begin{tabular}{|c|c|c|c|c|c|c|c|c|c|c|}
\hline \multicolumn{7}{|c|}{ The initial decision making matrix } & & & & \\
\hline \multirow{2}{*}{ Alternatives } & \multicolumn{6}{|c|}{ Attributes } & & & & \\
\hline & $x_{1}$ & $x_{2}$ & $x_{3}$ & $x_{4}$ & $x_{5}$ & $x_{6}$ & & & & \\
\hline Optimum & $\min$ & $\min$ & $\min$ & $\min$ & $\min$ & $\min$ & & & & \\
\hline Weights $w$ & 0.212 & 0.244 & 0.200 & 0.172 & 0.082 & 0.090 & & & & \\
\hline$a_{1}$ & 9.7 & 405 & 3.53 & 247 & 2 & 13.9 & & & & \\
\hline$a_{2}$ & 10.2 & 429 & 3.53 & 247 & 2.5 & 9.3 & & & & \\
\hline$a_{3}$ & 8.6 & 404 & 3.38 & 495 & 2 & 16.2 & & & & \\
\hline$a_{4}$ & 9.8 & 320 & 3.38 & 246 & 2.3 & 7.8 & & & & \\
\hline$a_{5}$ & 7.9 & 327 & 3.53 & 247 & 2.2 & 13.8 & & & & \\
\hline \multicolumn{11}{|c|}{ TOPSIS method } \\
\hline & $\hat{x}_{1}$ & $\hat{x}_{2}$ & $\hat{x}_{3}$ & $\hat{x}_{4}$ & $\hat{x}_{5}$ & $\hat{x}_{6}$ & $D^{+}$ & $D^{-}$ & $K$ & Rank \\
\hline Optimum & $\min$ & $\min$ & $\min$ & $\min$ & $\min$ & $\min$ & & & & \\
\hline$a_{1}$ & 0.099 & 0.116 & 0.091 & 0.061 & 0.033 & 0.044 & 0.036 & 0.075 & 0.673 & 3 \\
\hline$a_{2}$ & 0.104 & 0.123 & 0.091 & 0.061 & 0.042 & 0.030 & 0.041 & 0.075 & 0.649 & 4 \\
\hline$a_{3}$ & 0.088 & 0.116 & 0.087 & 0.122 & 0.033 & 0.052 & 0.071 & 0.013 & 0.158 & 5 \\
\hline$a_{4}$ & 0.100 & 0.092 & 0.087 & 0.061 & 0.038 & 0.025 & 0.020 & 0.094 & 0.824 & 1 \\
\hline$a_{5}$ & 0.081 & 0.094 & 0.091 & 0.061 & 0.037 & 0.044 & 0.020 & 0.090 & 0.819 & 2 \\
\hline$a^{+}$ & 0.081 & 0.092 & 0.087 & 0.061 & 0.033 & 0.025 & 0.000 & 0.108 & 1.000 & \\
\hline$a^{-}$ & 0.104 & 0.123 & 0.091 & 0.122 & 0.042 & 0.052 & 0.078 & 0.000 & 0.000 & \\
\hline
\end{tabular}

\section{COPRAS method}

\begin{tabular}{l|c|c|c|c|c|c|c|c|r|r|r}
\hline & $\hat{x}_{1}$ & $\hat{x}_{2}$ & $\hat{x}_{3}$ & $\hat{x}_{4}$ & $\hat{x}_{5}$ & $\hat{x}_{6}$ & $S_{-}$ & $S_{+}$ & $S$ & $K$ & Rank \\
\hline Optimum & $\min$ & $\min$ & $\min$ & $\min$ & $\min$ & $\min$ & & & & & \\
\hline$a_{1}$ & 0.045 & 0.052 & 0.041 & 0.029 & 0.015 & 0.020 & 0.000 & 0.202 & 0.197 & 0.905 & 3 \\
\hline$a_{2}$ & 0.047 & 0.055 & 0.041 & 0.029 & 0.019 & 0.014 & 0.000 & 0.204 & 0.195 & 0.895 & 4 \\
\hline$a_{3}$ & 0.040 & 0.052 & 0.039 & 0.058 & 0.015 & 0.024 & 0.000 & 0.227 & 0.175 & 0.804 & 5 \\
\hline$a_{4}$ & 0.045 & 0.041 & 0.039 & 0.029 & 0.017 & 0.011 & 0.000 & 0.183 & 0.218 & 1.000 & 1 \\
\hline$a_{5}$ & 0.036 & 0.042 & 0.041 & 0.029 & 0.016 & 0.020 & 0.000 & 0.185 & 0.215 & 0.989 & 2 \\
\hline
\end{tabular}

ARAS method

\begin{tabular}{l|l|l|l|l|l|l|l|r|r|r|}
\hline & $\hat{x}_{1}$ & $\hat{x}_{2}$ & $\hat{x}_{3}$ & $\hat{x}_{4}$ & $\hat{x}_{5}$ & $\hat{x}_{6}$ & & $S$ & $K$ & Rank \\
\hline Optimum & min & $\min$ & $\min$ & $\min$ & $\min$ & $\min$ & & \\
\hline$a_{1}$ & 0.040 & 0.045 & 0.039 & 0.038 & 0.018 & 0.015 \\
\hline$a_{2}$ & 0.038 & 0.042 & 0.039 & 0.038 & 0.014 & 0.022 \\
\hline$a_{3}$ & 0.045 & 0.045 & 0.041 & 0.019 & 0.018 & 0.013 & 0.195 & 0.897 & 3 \\
\hline$a_{4}$ & 0.040 & 0.057 & 0.041 & 0.038 & 0.016 & 0.026 & & 0.194 & 0.893 & 4 \\
\hline$a_{5}$ & 0.049 & 0.055 & 0.039 & 0.038 & 0.016 & 0.015 & 0.181 & 0.831 & 5 \\
\hline$a_{0}$ & 0.049 & 0.057 & 0.041 & 0.038 & 0.018 & 0.026 & & 0.217 & 1.000 & 1 \\
\hline
\end{tabular}

\section{Conclusions}

Overall, the main advantages that the MCDM provides in decision making could be summarized in the following aspects: the possibility to analyse complex problems; the possibility to aggregate both quantitative and qualitative criteria in the evaluation process; good evidence of decisions; the option for a decision-maker to participate actively in the decision-making process; and the use of flexible scientific methods in the decision making process.

According to the newly proposed model, the priorities of alternatives can be determined according to the utility function value. Consequently, it is convenient to evaluate and rank decision alternatives when this model is used.

The degree of the alternative utility is determined by comparison of the analysed variant with ideally the best one.

It can be stated that the ratio with an optimal alternative may be used in cases when it is required to rank alternatives and find ways to improve alternative projects.
Three MCDM methods were applied. Alternatives according to all methods rank in the same way: $a_{4} \succ a_{5} \succ a_{1} \succ a_{2} \succ a_{3}$.

This means that the most preferable alternative is $a_{4}$ that must be selected and implemented.

The proposed model can be modified and applied to solve different problems: to select, assess and rank constructions, technologies and other alternatives.

\section{References}

Banaitienè, N.; Banaitis, A.; Norkus, A. 2011. Risk management in projects: peculiarities of Lithuanian construction companies, International Journal of Strategic Property Management 15(1): 60-73.

http://dx.doi.org/10.3846/1648715X.2011.568675

Bindu Madhuri, C.; Anand Chandulal, J.; Padmaja, M. 2010. Selection of best web site by applying COPRAS-G method, International Journal of Computer Science and Information Technologies 1(2): 138-146.

Chatterjee, P.; Athawale, V. M.; Chakraborty, S. 2011. Materials selection using complex proportional assessment and 
evaluation of mixed data methods, Materials \& Design 32(2): 851-860.

http://dx.doi.org/10.1016/j.matdes.2010.07.010

Datta, S.; Beriha, G. S.; Patnaik, B.; Mahapatra, S. S. 2009. Use of compromise ranking method for supervisor selection: a multi-criteria decision making (MCDM) approach, International Journal of Vocational and Technical Education 1(1): 7-13.

Dzemyda, G.; Sakalauskas, L. 2011. Large-scale data analysis using heuristic methods, Informatica 22(1): 1-10.

Ergu, D.; Kou, G.; Peng, Y.; Shi, Y. 2011 b. A simple method to improve the consistency ratio of the pair-wise comparison matrix in ANP, European Journal of Operational Research 213(1): 246-259.

http://dx.doi.org/10.1016/j.ejor.2011.03.014

Ergu, D.; Kou, G.; Shi, Y.; Shi, Y. 2011a. Analytic network process in risk assessment and decision analysis, Сотрuters \& Operations Research (in press).

http://dx.doi.org/10.1016/j.cor.2011.03.005

Fisher, R. A.; Yates, F. 1963. Statistical tables for biological, agricultural and medical research. $6^{\text {th }}$ ed. Edinburgh: Oliver and Boyd. $156 \mathrm{p}$.

Hwang, C. L.; Yoon, K. 1981. Multiple Attribute Decision Making, in Lecture Notes in Economics and Mathematical Systems 186, Berlin: Springer-Verlag. 259 p.

Kaklauskas, A.; Rute, J.; Gudauskas, R.; Banaitis, A. 2011. Integrated model and system for passive houses multiple criteria analysis, International Journal of Strategic Property Management 15(1): 74-90.

http://dx.doi.org/10.3846/1648715X.2011.574903

Kalibatas, D.; Zavadskas, E. K.; Kalibatiene, D. 2011. The concept of the ideal indoor environment in multi-attribute assessment of dwelling-houses, Archives of Civil and Mechanical Engineering 11(1): 89-101.

Kendall, M. G. 1970. Rank correlation methods. $4^{\text {th }}$ ed. London: Griffin. 210 p.

Keršulienè, V.; Turskis, Z. 2011. Integrated fuzzy multiple criteria decision making model for architect selection, Technological and Economic Development of Economy 17(4): 645-666.

http://dx.doi.org/10.3846/20294913.2011.635718

Keršuliene, V.; Zavadskas, E. K.; Turskis, Z. 2010. Selection of rational dispute resolution method by applying new stepwise weight assessment ratio analysis (SWARA), Journal of Business Economics and Management 11(2): 243-258.

Krayushkina, K.; Prentkovskis, O.; Bieliatynskyi, A.; Junevičius, R. 2012. Use of steel slags in automobile road construction, Transport 27(2): 129-137.

http://dx.doi.org/10.3846/16484142.2012.690093

Maskeliūnaite, L.; Sivilevičius, H.; Podvezko, V. 2009. Research on the quality of passenger transportation by railway, Transport 24(2): 100-112.

http://dx.doi.org/10.3846/1648-4142.2009.24.100-112

Medineckiene, M.; Turskis, Z.; Zavadskas, E. K. 2010. Sustainable construction taking into account the building impact on the environment, Journal of Environmental Engineering and Landscape Management 18(2): 118-127. http://dx.doi.org/10.3846/10.3846/jeelm.2010.14

Merigo, J. M.; Gil-Laufente, A. M. 2011. OWA operators in human resource management, Economic Computation and Economic Cybernetics Studies and Research 45(2): 153-168.

Nieto-Morote, A.; Ruz-Vila, F. 2011. A fuzzy AHP multicriteria decision-making approach applied to combined cooling, heating, and power production systems, Interna- tional Journal of Information Technology \& Decision Making 10(3): 497-518.

http://dx.doi.org/10.1142/S0219622011004427

Peng, Y.; Kou, G.; Wang, G.; Shi, Y. 2011. FAMCDM: a fusion approach of MCDM methods to rank multiclass classification algorithms, Omega 39(6): 677-689.

http://dx.doi.org/10.1016/j.omega.2011.01.009

Podvezko, V. 2011. The comparative analysis of MCDA methods SAW and COPRAS, Inzinerine Ekonomika - Engineering Economics 22(2): 126-133.

Prentkovskis, O.; Tretjakovas, J.; Švedas, A.; Bieliatynskyi, A.; Daniūnas, A.; Krayushkina, K. 2012. The analysis of the deformation state of the double-wave guardrail mounted on bridges and viaducts of the motor roads in Lithuania and Ukraine, Journal of Civil Engineering and Management 18(5): 761-771.

http://dx.doi.org/10.3846/13923730.2012.731252

Raslanas, S.; Alchimovienè, J.; Banaitienè, N. 2011. Residential areas with apartment houses: analysis of the condition of buildings, planning issues, retrofit strategies and scenarios, International Journal of Strategic Property Management 15(2): 152-172.

http://dx.doi.org/10.3846/1648715X.2011.586531

Rudzianskaite-Kvaraciejiene, R.; Apanaviciene, R.; Butauskas, A. 2010. Evaluation of road investment project effectiveness, Inzineriné Ekonomika - Engineering Economics 21(4): 368-376.

Saaty, L. T. 1980. The Analytic Hierarchy Process. New York: McGraw Hill. 287 p.

Saaty, T. L.; Zoffer, H. J. 2011. Negotiating the IsraeliPalestinian controversy from a new perspective, International Journal of Information Technology \& Decision Making 10(1): 5-64.

http://dx.doi.org/10.1142/S021962201100421X

San Cristóbal, J. R. 2012. Contractor Selection Using Multicriteria Decision-Making Methods, Journal of Construction Engineering and Management 138(6): 751-758. http://dx.doi.org/10.1061/(ASCE)CO.1943-7862.0000488

Sivilevičius, H. 2011a. Modelling the interaction of transport system elements, Transport 26(1): 20-34. http://dx.doi.org/10.3846/16484142.2011.560366

Sivilevicius, H. 2011 b. Application of expert evaluation method to determine the importance of operating asphalt mixing plant quality criteria and rank correlation, The Baltic Journal of Road and Bridge Engineering 6(1): 48-58. http://dx.doi.org/10.3846/bjrbe.2011.07

Sivilevičius, H.; Daniūnas, A.; Zavadskas, E. K.; Turskis, Z.; Sušinskas, S. 2012. Experimental study on technological indicators of pile-columns at a construction site, Journal of Civil Engineering and Management 18(4): 512-518. http://dx.doi.org/10.3846/13923730.2012.709958

Sivilevičius, H.; Maskeliūnaitè, L. 2010. The criteria for identifying the quality of passengers' transportation by railway and their ranking using AHP method, Transport 25(4): 368-381. http://dx.doi.org/10.3846/transport.2010.46

Sušinskas, S.; Zavadskas, E. K.; Turskis, Z. 2011. Multiple criteria assessment of pile-columns alternatives, The Baltic Journal of Road and Bridge Engineering 6(3): 77-83.

Šaparauskas, J.; Zavadskas, E. K.; Turskis, Z. 2011. Selection of facade's alternatives of commercial and public buildings based on multiple criteria, International Journal of Strategic Property Management 15(2): 189-203. http://dx.doi.org/10.3846/1648715X.2011.586532

Tomlinson, M. J.; Woodward, J. 2008. Pile Design and Construction Practice. 5th ed. Taylor \& Francis. 568 p. 
Turskis, Z.; Zavadskas, E. K. 2010a. A new fuzzy additive ratio assessment method (ARAS-F). Case study: the analysis of fuzzy multiple criteria in order to select the logistic centers location, Transport 25(4): 423-432. http://dx.doi.org/10.3846/transport.2010.52

Turskis, Z.; Zavadskas, E. K. 2010b. A novel method for multiple criteria analysis: grey additive ratio assessment (ARAS-G) method, Informatica 21(4): 597-610.

Uzsilaityte, L.; Martinaitis, V. 2010. Search for optimal solution of public building renovation in terms of life cycle, Journal of Environmental Engineering and Landscape Management 18(2): 102-110. http://dx.doi.org/10.3846/jeelm.2010.12

Vaidogas, E. R.; Sakenaite, J. 2011. Multi-attribute decisionmaking in economics of fire protection, Inzinerine Ekonomika - Engineering Economics 22(3): 262-270.

Wu, W.; Kou, G.; Peng, Y.; Ergu, D. 2012. Improved AHPgroup decision making for investment strategy selection, Technological and Economic Development of Economy 18(2): 299-316. http://dx.doi.org/10.3846/20294913.2012.680520

Yazdani, M.; Alidoosti, A.; Zavadskas, E. K. 2011. Risk analysis of critical infrastructures using fuzzy COPRAS, Ekonomska istrazivanja - Economic Research 24(4): 27-40.

Yoon, S.; Tsai, C.; Melton, J. M. 2011. Pile load test and implementation of specifications of load and resistance factor design: case study of Caminada Bay Bridge Project in Louisiana, Transportation Research Record: Journal of the Transportation Research Board 2212: 23-33. http://dx.doi.org/10.3141/2212-03

Zavadskas, E. K.; Kaklauskas, A. 1996. Determination of an efficient contractor by using the new method of multicriteria assessment, in Langford, D. A.; Retik, A. (Eds.). International Symposium for "The Organisation and Management of Construction". Shaping Theory and Practice. Vol. 2: Managing the Construction Project and Managing Risk. CIB W 65; London, Weinheim, New York, Tokyo, Melbourne, Madras. London: E and FN SPON, 94-104.

Zavadskas, E. K.; Liias, R.; Turskis, Z. 2008. Multi-attribute decision-making methods or assessment of quality in bridges and road construction: state-of-the-art surveys, Baltic Journal of Road and Bridge Engineering 3(3): 152-168.

Zavadskas, E. K.; Turskis, Z. 2010. A new additive ratio assessment (ARAS) method in multicriteria decisionmaking, Technological and Economic Development of Economy 16(2): 159-172.

http://dx.doi.org/10.3846/tede.2010.10

Edmundas Kazimieras ZAVADSKAS. Dr Habil, Professor, Head of the Research Institute of Internet and Intelligent Technologies and Head of the Department of Construction Technology and Management of Vilnius Gediminas Technical University, Lithuania. Research interests: building technology and management, decision-making theory, automation in design and decision support systems.

Saulius SUŠINSKAS. Doctor, Associate Professor, Head of the Department of Civil Engineering of Panevėžys Institute Faculty of Technologies, Kaunas University of Technology, Lithuania. Research interests: civil engineering, construction materials and their strength and durability, analysis of changes in substrate stiffness and its effect on the behaviour of the building.

Alfonsas DANIŪNAS. Doctor, Associate Professor at the Department of Steel and Timber Structures of Vilnius Gediminas Technical University, Lithuania. Research interests: analysis and optimization of elastic and plastic steel structures, numerical methods, semi-rigid joints of steel structures.

Zenonas TURSKIS. Doctor of Technical Science, Chief Research Fellow at Construction Technology and Management Laboratory of Vilnius Gediminas Technical University. Research interests: civil engineering, construction technology and management, decision-making theory, computer-aided automation in design, expert systems.

Henrikas SIVILEVIČIUS. Dr Habil, Professor at the Department of Transport Technological Equipment of Vilnius Gediminas Technical University, Lithuania. Research interests: flexible pavement life-cycle, hot mix asphalt mixture production technology, application of statistical and quality control methods, recycling asphalt pavement technologies and design, decision-making and expert systems theory.
Zavadskas, E. K.; Turskis, Z. 2011. Multiple criteria decision making (MCDM) methods in economics: an overview, Technological and Economic Development of Economy 17(2): 397adskas, E. K.; Turskis, Z.; Ustinovičius, L.; Ševčenko, G

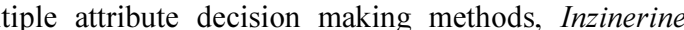
dskas, E. K.; Turskis, Z.; Vilutiene, T. 2010b. Multiple

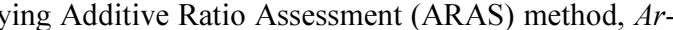
chives of Civil and Mechanical Engineering 10(3): 123141. http://dx.doi.org/10.1016/S1644-9665(12)60141-1 11(2): 501-520

Zeleny, M. 1982. Multiple Criteria Decision Making. New York: McGraw-Hill. 563 p. 136(11): 1475-1488

Zhang, R.; Zheng, J.; Pu, H.; Zhang, L. 2011b. Analysis of

Zhang, R.-J.; Zheng, J.-J.; Zhang, L.-M.; Pu, H.-F. 2011a. An analysis method for the influence of tunnelling on adjaant loaded pile groups with rigid elevated caps, InternaGeomechanics 35(18): 1949-1971.

for stability analysis of high pile-column bridge pier, Journal of Central South University of Technology 14(5): 725-729. http://dx.doi.org/10.1007/s11771-007-0138-5 of Highway and Transportation Research and Development 4(1): 40-44. 